\title{
IMPLEMENTASI PROGRAM DETEKSI DINI KANKER SERVIKS MELALUI METODE INSPEKSI VISUAL ASAM ASETAT (IVA) DI PUSKESMAS BOJONGSARI KOTA DEPOK TAHUN 2018
}

\author{
Amalia Nurazizah $^{1}$, Indira Chotimah' ${ }^{2}$ Suci Pujiati ${ }^{3}$ \\ ${ }^{1}$ Konsentrasi Manajemen Pelayanan Kesehatan (MPK), Program Studi Kesehatan Masyarakat Fakultas Ilmu Kesehatan \\ Universitas Ibn Khaldun Bogor. Jl. KH. Sholeh Iskandar Raya KM 2, Kedung Badak, Bogor 16161, Jawa Barat, \\ Email : Ame19aks2011@gmail.com \\ ${ }^{2}$ Konsentrasi Manajemen Pelayanan Kesehatan (MPK), Program Studi Kesehatan Masyarakat Fakultas Ilmu Kesehatan \\ Universitas Ibn Khaldun Bogor. Jl. KH. Sholeh Iskandar Raya KM 2, Kedung Badak, Bogor 16161, Jawa Barat \\ Email: Indira.chotimah@gmail.com \\ ${ }^{3}$ Konsentrasi Manajemen Pelayanan Kesehatan (MPK), Program Studi Kesehatan Masyarakat Fakultas Ilmu Kesehatan \\ Universitas Ibn Khaldun Bogor. Jl. KH. Sholeh Iskandar Raya KM 2, Kedung Badak, Bogor 16161, Jawa Barat \\ Email : Pujiati.suci@gmail.com
}

\begin{abstract}
Abstrak
Tahun 2016 kanker serviks terjadi sebanyak 492 kasus di puskesmas. Kanker Serviks tertinggi terjadi pada kelompok umur 45 - 64 tahun sebesar 4.082 kasus di rumah sakit. Di Jawa Barat, kejadian kanker serviks sebanyak 500 kasus. Sebagai bentuk upaya deteksi dini dapat dilakukan dengan metode Inspeksi Visual Asam Asetat dan Krioterapi untuk kanker serviks. Penelitian ini bertujuan untuk mengetahui Implementasi Program Deteksi Dini Kanker Serviks melalui Metode Inspeksi Visual Asam Asetat (IVA) di Puskesmas Bojongsari Kota Depok. Penelitian ini menggunakan metode kualitatif dengan teknik pengumpulan data menggunakan wawancara mendalam, observasi dan telaah data. Populasi pada penelitian ini adalah seluruh petugas di puskesmas Bojongsari. Penelitian ini terdiri dari 8 orang informan dengan 1 informan kunci dan 7 informan inti. Hasil penelitian menunjukkan bahwa Implementasi program deteksi dini kanker serviks melalui metode IVA di puskesmas bojongsari kota depok dapat dikatakan baik. Perlu ditingkatkan sosialisasi dan penyuluhan ke kader juga warga setempat agar puskesmas cakupannya tercapai.
\end{abstract}

\section{Kata Kunci : Implementasi, Serviks, IVA}

\section{Pendahuluan}

Berdasarkan data Globocan, International Agency for Research (IARC) 2012, Kanker Serviks menempati urutan kedua seluruh kanker pada perempuan dengan incidence rate 17 per 100.000 perempuan, kasus baru yang ditemukan $13,0 \%$ dengan jumlah kematian 10,3\% per tahun dari seluruh kasus kanker pada perempuan di dunia (Kemenkes, 2015).

Di Indonesia Kanker Serviks di tahun 2016 terjadi sebanyak 492 kasus di puskesmas. Kasus kanker Serviks tertinggi terjadi pada kelompok umur 45 - 64 tahun sebesar 4.082 kasus di rumah sakit. Di Jawa Barat, kejadian kanker serviks sebanyak 500 kasus. (Profil Penyakit Tidak Menular, 2016)
Penyebab primer kanker leher rahim adalah infeksi kronik leher rahim oleh satu atau lebih virus HPV (Human Papiloma Virus) tipe onkogenik yang berisiko tinggi menyebabkan kanker leher rahim, ditularkan melalui hubungan seksual.(Sulistiowati dan Sirait, 2014). Kanker Serviks adalah kanker paling umum keempat pada wanita di seluruh dunia, tetapi sebagian besar kematian ini dapat dicegah dengan langkah-langkah pencegahan yang memadai, seperti vaksinasi anak perempuan terhadap human papilomavirus (HPV) dan program skrining untuk mendeteksi dan mengobati lesi prakanker (IARC, 2017).

Berdasarkan Peraturan Menteri Kesehatan Nomor 34 Tahun 2015 tentang Penanggulangan Kanker Payudara dan Kanker Leher Rahim bahwa sebagai bentuk upaya deteksi dini kanker 
serviks dapat dilakukan dengan metode Inspeksi Visual Asam Asetat (IVA) dan Krioterapi untuk kanker serviks. Inspeksi Visual Asam Asetat (IVA) adalah pemeriksaan dengan cara mengamati dengan menggunakan speculum, melihat leher rahim yang telah dipulas dengan asam asetat atau asam cuka (3-5\%). Pada lesi prakanker akan menampilkan warna bercak putih disebut acetowhite epitelium. IVA adalah praktik yang dianjurkan untuk fasilitas dengan sumber daya sederhana (Kemenkes, 2015).

Kementrian Kesehatan Republik Indonesia menetapkan target cakupan deteksi dini sampai tahun 2017 mencapai 30\%.(Kemenkes, 2015) Cakupan pemeriksaan di Indonesia hingga tahun 2017 mencapai 2,978\%. Cakupan pemeriksaan di Jawa Barat Tahun 2017 mencapai 1,006\% (Infodatin, 2017). Didapatkan IVA positif sebanyak 4,606 orang (Profil Kesehatan Jawabarat, 2017).

Berdasarkan data profil Dinas Kesehatan Kota Depok tahun 2017, cakupan pemeriksaan deteksi dini kanker serviks dengan metode IVA sebanyak $0,83 \%$ dari total perempuan usia $30-$ 50 tahun. Dari data tersebut, masih rendahnya cakupan pemeriksaan dari target yang ditentukan Kemenkes yaitu $30 \%$ dari jumlah perempuan usia 30 - 50 tahun.

Puskesmas Bojongsari adalah puskesmas yang berada di kota Depok yang mencakup 4 kelurahan. Di tahun 2017, puskesmas bojongsari melakukan 191 pemeriksaan deteksi dini kanker servik melalui metode IVA dari target perempuan usia 30 - 50 tahun sebanyak 12.786. Masih rendahnya cakupan pemeriksaan ini yang melatar belakangi peneliti untuk menjadikan Puskesmas Bojongsari sebagai tempat penelitian.

Berdasarkan pemaparan diatas, maka peneliti tertarik dalam menganalisis terkait dengan implementasi program deteksi dini kanker serviks melalui metode IVA di Puskesmas Bojongsari Kota Depok tahun 2018.

\section{Metodologi Penelitian}

Penelitian ini dilakukan di Puskesmas Bojongsari Kota Depok pada bulan Februari - April 2019. Penelitian ini merupakan penelitian kualitatif dengan populasi seluruh petugas kesehatan di puskesmas bojongsari, dan informan yang terdiri dari 1 orang penanggung jawab program, 1 orang kepala puskesmas, 2 orang bidan pelaksana, dan 4 orang kader. Dari topic penelitian diatas, penelitian ini untuk mengetahui input yaitu man, money, method, material, machine yang berkaitan dengan program IVA, juga proses yang terdiri dari Sumber Daya, Komunikasi, Struktur Birokrasi dan Disposisi yang berpengaruh pada output, yaitu Implementasi Program IVA di Puskesmas Bojongsari Tahun 2018.

\section{Hasil Penelitian}

\section{Karakteristik Informan}

Informan dalam penelitian ini berjumlah 8 orang yang terdiri dari 2 orang bidan pelaksana, 1 orang kepala puskesmas, dan 4 orang kader. semua informan memiliki rentang umur 3051 Tahun dengan latar belakang pendidikan 3 orang kebidanan, 1 orang kedokteran, 2 Orang SMA, 1 orang S1 dan 1 Orang D3. Untuk kader, rata rata menjabat sebagai kader $>5$ Tahun.

\section{Input \\ Man}

informan yang ditanyakan terkait jumlah sumber daya program IVA menjawab sebanyak 10 orang, dan jumlahnya sudah mencukupi. Berikut kutipan wawancaranya :

"...jadiii bidan pns kita ada 4 bidan swakelola kita ada enaam..” (Informan 1)

Hal ini sejalan dengan pernyataan dari 3 informan yang di beri pertanyaan terkait bidan yang melaksanakan pemeriksaan IVA. berikut kutipan wawancaranya :

“......sekarang.. untuk bidan kan empat... eeee bidan ASN ya... untuk bidan swakelolanya.. ada enem.. 10 ya... iya......." (Informan 2)

“......Cukup sih menurut saya. Bidan itu kita yang pnsnya ada empaaat, yang swakelolanya dalam artian non pns yaaaa, non pns itu ada termasuk bidan poned itu adaaaa tije, gita, enur, yeye, asri, enam.. jadi total bidan ada 10." (Informan 3) 
“....Sebenernya

semua

bidan

terlibat..."(Informan 4)

Money

Pembiayaan pada pemeriksaan iva ini dikenakan biaya sebesar 25.000 dan apabila menggunakan BPJS tidak dikenakan biaya. Berikut kutipan wawancaranya:

"Pembiayaannya ya kalau pakai BPJS ya gratis.. kalau gak pake BPJS bayar dua puluh lima ribu.. ada di perda......" (Informan 3)

".....kalau umum itu dia bayar. dua puluh lima ribu... dan daftar yah.. dua ribu... terus kalo yang punya.. BPJS... samaaa KIS sini ya... tapi faskes sini ya... bisa..." (Informan 2) "Kalo yang bpjs gratis.. kalo pasien umum bayar duapuluh lima ribu..” (Informan 1)

Dari keempat kader yang ditanyakan, semua kader menyatakan bahwa pembiayaan untuk pemeriksaan iva gratis. Berikut kutipan wawancaranya :

"Biasanya sih dari puskesmas gratis... kalo seandainya mau pribadi.. biasanya kan di puskesmas ada. Duapuluh lima ribu..." (Informan 5)

"ada... yang gratis... itu.. kalo soal harga saya kurang tau juga ya...” (Informan 6)

Method

Metode yang digunakan untuk pelaksanaan program IVA berupa kegiatan didalam gedung saja pada saat pelayanan $\mathrm{KB}$, sekalipun ada program tahunan tetap dilakukan di dalam gedung ataupun kerjasama dengan bidan swasta. Berikut kutipan wawancaranya :

"jadi sekalian pemeriksaan IUD.. control IUD.. pemasangan IUD.. itu biasa kita langsung pemeriksaan.. pemeriksaannya. Yaa maksudnyaa ya.. seperti pemeriksaan iva pada umumnya.. kalo kitaa.. khusus kita dialem gedung ini aja... .kalo yaanggg kita gak pernah mobile ke lapangaann... kalopun ada program yang satu taun satu kali itu.. tapi tetep didalem gedung sendiri.." (Informan 1)

"dilaksanakan seminggu sekali setiap hari raabuu ya sudah dilaksanakan diruang poli KIA...... Kalau diluar, kemaren setaun sekaliii ngadainnyaaa untuk IVAnyaaa ya tergantung dengan bekerjasamanya..

kadernya......." (Informan 3)

“....biasanya kalo yang iva itu puskesmas.. selain sama puskesmas sama klinik...” (Informan 7)

\section{Machine}

Berdasarkan hasil observasi, alat yang digunakan untuk pemeriksaan IVA yaitu :

Tabel 1. Alat Pemeriksaan IVA

\begin{tabular}{|c|c|c|c|c|}
\hline \multirow[b]{2}{*}{ No } & \multirow[b]{2}{*}{ Nama Alat } & \multicolumn{2}{|c|}{ Jumlah } & \multirow[b]{2}{*}{ Keadaan } \\
\hline & & $\begin{array}{c}\text { Permenkes } \\
\text { No } 34 \text { Tahun } \\
2015\end{array}$ & $\begin{array}{l}\text { Puskesmas } \\
\text { Bojongsari }\end{array}$ & \\
\hline 1 & Lampu Sorot & 1 & 1 & Baik \\
\hline 2 & $\begin{array}{l}\text { Spekulum } \\
\text { S,M,L }\end{array}$ & 3 & $\begin{aligned} \mathrm{S} & =5 \\
\mathrm{M} & =20 \\
\mathrm{~L} & =5\end{aligned}$ & Baik \\
\hline 4 & $\begin{array}{l}\text { Wadah } \\
\text { Spekulum }\end{array}$ & 1 & 1 & Baik \\
\hline 5 & $\begin{array}{l}\text { Ember } \\
\text { Ukuran } \\
\text { sedang }\end{array}$ & 3 & 1 & Baik \\
\hline 6 & Kapas Lidi & 4-5/Pasien & $\begin{array}{l}1-2 / \\
\text { Pasien }\end{array}$ & Baik \\
\hline 7 & $\begin{array}{l}\text { Cuka / asam } \\
\text { asetat 3-5\% }\end{array}$ & $\begin{array}{c}100 \mathrm{~mL} / 200 \\
\text { Pasien }\end{array}$ & $200 \mathrm{~mL}$ & Baik \\
\hline 8 & Klorin & $\begin{array}{l}500 \mathrm{~mL} \\
\text { /Pasien }\end{array}$ & $500 \mathrm{~mL}$ & Baik \\
\hline 9 & Sarung tangan & $\begin{array}{c}2-4 \\
\text { Buah/Pasien }\end{array}$ & 2/Pasien & Baik \\
\hline 10 & Kain & 1 & 1 & Baik \\
\hline 11 & $\begin{array}{l}\text { Tempat tidur/ } \\
\text { meja periksa }\end{array}$ & 1 & 1 & Baik \\
\hline 12 & Kursi periksa & 1 & 1 & Baik \\
\hline 13 & $\begin{array}{l}\text { Ruangan } \\
\text { periksa }\end{array}$ & 1 & 1 & Baik \\
\hline 14 & Wadah Plastik & 3 & $\begin{array}{l}3 \text { wadah } \\
\text { stainless }\end{array}$ & Baik \\
\hline
\end{tabular}

Dari seluruh informan sebagian menjawab alat yang digunakan berupa kapas lidi, speculum dan larutan asam asetat. Berikut kutipan wawancaranya :

"Alatnya ya pake speculum, pake apa namanya.. lidi itu lidi kapas lidi sama larutan cukaaa.." (Informan 3)

".......itukan pake cairan asetat.. itu cairannya pake satu banding empaat... jadi lima... trus pake apaa.. itu.. eee ituu.. kapas lidi..." (Informan 2) 
Pernyataan ini sejalan dengan pernyataan coordinator bidan. Berikut kutipan wawancaranya :

"....paling pake speculum aja sama asam asetaatt gak masalah sih yaa..” (Informan 1)

\section{Material}

Hasil penelitian menunjukkan bahwa semua informan menyatakan fasilitas yang terdapat untuk pemeriksaan IVA sudah cukup. Berikut kutipan wawancaranya :

"...Kalo fasilitas sih sama aja sih yaaa .......gak masalah sih yaa.." (Informan 1)

Pernyataan tersebut sejalan dengan pernyataan yang diungkapkan oleh informan lain. Berikut kutipan wawancaranya :

“.....Cukup.. ya ada.. gitu.. kalau sudah sering dilaksanakan berarti kan artinya medianya pun sudah ada gitukan..." (Informan 3)

“...Alhamdulillah eee ada memadai semua..." (Informan 4)

“....Ya.. kayaknya sih lumayan bagus..." (Informan 5)

Beberapa informan menyatakan bahwa Sarana dan Prasarana yang ada untuk pemeriksaan IVA berupa lampu, bed obgyn dan jumlahnya 1, juga form lembar IVA. Berikut kutipan wawancaranya :

"semua sih yaaa alat lampu ya itu apa namanya tempat tidur ginekologi... trus sama form lembaran IVA..." (Informan 3)

"Kalau IVA untuk kita Obgyn Bednya baru satu.." (Informan 2)

3. Proses

\section{Sumber Daya}

sumber daya untuk pemeriksaan iva merupakan bidan ataupun dokter yang telah terlatih. Berikut kutipan wawancaranya : "harus.. harus bener bener.. haruus.. apa ya namanya. punya keterampilan kompetensi.. khusus... karna.. eeee yaitu... kita gak bisa sembarangan membaca..." (Informan 1)
Hal ini sejalan dengan pernyataan dari 3 informan lain. Berikut kutipan wawancaranya:

"Iya.. harus ada.. jadi tenaga yang sudah terlatih sebenernya... karna pemeriksaan IVA kan tidak segampang eee.. kalau misalkan orang yang belum dilatih... apalagi misalnya dia jarang megang..." (Informan 3)

“...mungkin haruuss ada pelatihan yah.. haruss ada pelatihaan... eee cek pemeriksaan kanker.. gituu.. perlu sih itu pelatihanya..." (Informan 2)

“.....Jadi dinas pernah mengadakan pelatihan.. biasanya.. eee dokter dan bidan... untuk eee cara bagaimana melakukan tes iva... baik itu pap smear maupun dengan tes iva..." (Informan 4)

Dari ketiga informan yang di tanya terkait pelatihan, belum ada yang pernah mengikuti pelatihan terkait dengan program IVA. berikut kutipan wawancaranya :

"Belum... saya belum pernah dilatih. mungkin nanti dinkes akan mengadakan lagi kali hehe... dulu waktu itu ada yang pernah pelatihan disini, itu satu dokter satu bidaaan.. tapi duaduanya pindahh sudah dari sini gituu." (Informan 3)

"Kalauu.. kita belum. beluumm.. jadi kita eeee dikasiiih. karna ikut ikut sering kaya gitu jadi ada yang ngasih tauu.. kaya dokter misalnya dokteeerr yayasan YKI nya... jadi ngasih tauuu... trus ngasihhh kayak fotofoto gituuu yang kira-kiranya positif.." (Informan 2)

"Belum.. paling makanya kalo pemeriksaan IVA itu paling saya... bu meilinaa..." (Informan 1)

Kewenangan yang terdapat dalam program IVA ini yaitu puskesmas dapat melakukan pemeriksaan iva, dilakukan oleh bidan dan laporan jumlah pemeriksaan setiap bulan. Berikut kutipan wawancaranya :

"selama ini ya hanya begitu.. missal ditunjuk nih sebagai pemegang program.. 
yaudah saya membuat laporaaan tiap bulan.. uyaudah gitu doaang..." (Informan 3)

“.....pelayanan IVA di puskesmas.. dan itu boleh dilakukan sama bidan.. gitu.." (Informan 2)

"buat di puskesmas ya... itu sudah berwenaangg karna itu ada aturanyya... maksudnya udah ada... ituuu pemeriksaan iva ini boleeh di puskesmaas... gituuu... trus ada juga perdanya... gitu... kaloo petugas, bidan itu juga boleh melaksanakan iva yah... bukan hanya.. dokter..." (Informan 1)

Dalam pelaksanaannya, kader pun berperan dalam program iva ini. Berikut kutipan wawancaranya :

"....yaitu.. menginformasikan, dia ntar berkoordinasi dengan dokter yang ada di dinas kesehatan..." (Informan 3)

"perannya kita membantu pelaksanaan kegiatan pas hari h nya... trus kemudian kita sosialisasi juga ke warga..." (Informan 8)

"....Kalo kader itu paling hanya menggerakan masyarakat...” (Informan 1)

Namun, belum adanya pelatihan kader untuk program IVA dari puskesmas. Berikut kutipan wawancaranya :

“...pelatihaan.. pelatihaan nggak adaaa... paling ituu sosialisasi sosialisasi ajaaa.. paling itu di lokmin, dikecamataan.." (Informan 2)

“...kalau kader kita gak pernah melatih untuk itu.. paling sosialisasi.. eee ca serviks.. sosialisasi pemeriksaan iva nya seperti apa..." (Informan 1)

“...pelatihan.. enggak... untuk mencari sasaran aja..” (Informan 4)

\section{Komunikasi}

Dari hasil penelitian, didapatkan bahwa seluruh informan telah mengetahui program iva. berikut kutipan wawancaranya :

“....untuk mencegaaahh ee apa deteksi dini kanker rahiimm.. ya..” (informan 2)

"itu luar biasa bagusnya... dan itu pemeriksaan sederhana.. tapi dapat mendeteksi sedini mungkin... kalo kita curiga memang ada kanker... diii serviks yaa.. " (Informan 1)

"jadi.. ee... sebagia ujung tombak... puskesmas wajib melakukan sosialisasi... deteksi dini... kanker ini..." (Informan 4)

“.....Iva itu ya cara mendeteksi dini kanker aja...." (Informan 5)

"kalo kita ivates jadi kita lebih tau lebih awal tau, penyakit kita, dirahim kita ada apa sih.." (Informan 6)

Salah satu bentuk penyaluran informasi IVA dari puskesmas yaitu pada saat lokakarya mini yang diadakan setahun sekali, berupa penyuluhan singkat ke Kader. Berikut kutipan wawancaranya :

"disampaikan padasaat di lokmiinn.. jadi ngasih tau nih misalnya eee bahaya ee maksudnya pentinya IVA kaya giniginii ya gaboleh giniginii yaa penyuluhan singkat... nanti si kadernya juga memberitahukan ke warga gitu..." (Informan 3)

Juga penyampaian informasi ke pasien yang datang ke puskesmas. Berikut kutipan wawancaranya :

“.....informasi... paling kita kasih tau ke ibunya... ke ibu ibu bayi dan balita... menginfokan kalau setiap hari rabu di puskesmas ada pelayanan ini ya..." (Informan 2)

“....selain kita ke kader.. kita ngomonginnya. stiaa.. ee setiap pasien... pasti kita omongin... ke setiap pasieen..." (Informan 1)

Penyaluran informasi dari kader ke masyarakat biasanya dari grup-grup di sosial media, pengajian ibu-ibu, dan kegiatan posyandu. Berikut kutipan wawancaranya :

"Di grup.. di grup posyandu... ada pokja 4 sih yang ngedata.." (Informan 5)

"kalo lagi posyandu kan ada di meja empat.. kita penyuluhan.. ke pengajian..."

(Informan 6) 
"kalo aku ketemu.. aku kasih tau.. kalo nggak di posyandu ya... lagi penimbangan... ibu-ibunya aku kabarin.. kalo misalkan gak mepet waktunya..." (Informan 7)

"biasanya sih kita ngadainnya lewat lewat acra kumpul warga yah seperti pengajiaan trus kita lagi acara penimbangaaan"

\section{(Informan 8)}

Disposisi

Puskesmas menyambut baik program IVA ini. Berikut kutipan wawancaranya :

"Yaaa.. bagus sih... untuk pencegahan dini kanker serviks... itu baguus... yaaharus terus dilakukannn programnya..." (Informan 2)

“....kita sih nggak masalah... maksudnya iya ada program ya oke.. oke aja.. yang penting kita atur waktu. atur tenaganya ada.. waktunya ada.. itu pasti kita laksanakan.." (Informan 1)

“....ya bagus sih.. kalau untuk deteksi dini awaall.. sebenernya IVA sama papsmear. kan sama-sama kan.. hanya untuk deteksi dini awal kanker serviks.. tapi dari segi harga.. segi cepatnya.. segi praktisnya.. IVA itu jauh lebih ini.. lebih unggul lah.. dari pada pap smear.." (Informan 3)

Program IVA ini juga ditanggapi positif oleh kader yang ada di wilayah kerja puskesmas. Berikut kutipan wawancaranya : "Alhamdulillah bermanfaat banget... apalgi untuk saya pribadi ya.....” (Informan 6)

“...bagus lah... eee membantu warga... supaya mengetahui sejak dini kanker serviks ya..." (Informan 7)

"....Alhamdulillah bagus.. karna eee kebetulan di warga kita itu eee produktif semua... gitu.. jadi saasarannnya lebih banyak... dan peminatnya Alhamdulillah banyak juga..." (Informan 8)

“....ternyata iva itu kaya gitu. gamasalah lahh.. wajar daripada istilah kata mencegah lebih baik daripada mengobati..." (Informan 5)

Puskesmas juga telah bekomitmen untuk terus melaksanakan IVA. berikut kutipan wawancaranya :

“...saya pikir eeee temen - teemen ini sudah cukup bagus ya... untuk komitmennyaa.. paling kalau kita sebagai.. tenaga.. kesehatan.. tapi saya dan... pelaksana... untuk melaksanakan itu... berarti sesuai dengan kewenangan saya aja... tapi untuk yang lainlainnya.. biasanya koordinasi dengan kepala puskesmas..." (Informan 1)

"sebenernya... untuk kanker serviks itu... ee menekan.. ee menekan... heeh.. penderita kanker... minimal masyarakat khususnya wanita.." (Informan 4)

"kita ya itu.. menjalankan ajasih setiap eeee kegiatannya IVA itu ya seminggu sekali.. yak an kita udah commit yak an. menjalankan itu.. ya.. udah... paling hanya penyuluhan.. penyuluhan.. aja.. kalau sedang diluar.. gituu.." (Informan 3)

\section{Struktur Birokrasi}

3 dari 4 informan yang ditanyakan terkait SOP menjawab bahwa terdapat SOP yang mengatur terkait program IVA. berikut kutipan wawancaranya :

"SOP itu ada nggak yaaa... Heehh pasti sih ada sih ya semua tindakan.. Cuma itukan masuknya ke UKP..." (Informan 3)

“.. ee sop yang mengaturnya... itukan udah ada contohnya... sop, saya nggak tahu sih tempatnya dimana.. harus cari dulu.. ada... sopnya.. kan tiap kegiatan itu harus ada.. sopnya..." (Informan 2)

"ada SOP.. setiap kita melakukan kegiatan mulai dari kerangka acuaan..." (Informan 4)

Salah satu informan menyatakan bahwa SOP untuk program IVA di puskesmas tidak ada, dikarenakan hanya program tambahan. Hal ini dikonfirmasi ketika telaah dokumen, penulis tidak menemukan dokumen untuk SOP program IVA. Berikut kutipan wawancaranya :

"SOpnya itu kalau untuk pelayanan iva khusus kayaknya enggak deh... maksudnya saya belum.. kayaknya sop disni kayaknya belum deh.. soalnya kalo misalnya.. sop untuk pelayanannya.. alurnya sama seperti eeeee seperti pemeriksaan yang lain... Cuma... kalo khusus iva kayaknya belum. soalnya itukan program tambahan.." (Informan 1) 


\section{Output}

seluruh informan menyatakan implementasi program IVA dipuskesmas sudah baik. Puskesmas terus berusaha untuk meningkatkan pelayanan terkait iva dengan rutin seminggu sekali. berikut kurtipan wawancaranya :

"Sejauh ini sudah berjalan bagus ya.." (Informan 4)

"Eeeealhamdulillah sih bagus sih mbak.. cuman.. yaitu... hanya saja.. kita untuk meee kadang orang khusus datang hanya untuk iva itu jarang... makanya kita biasa nangkepnya.. supaya iva ini tetep berjalan.. pada saat kita bersinggungan dengan $k b$.. bisa IUD, bisa control IUD, bisa pasang awal IUD... langsung kita periksakan..."

(Informan 1)

"kalau selama ini sih.. sudah berjalan sesuai dengan eee ini ya... karna kan memang setiap seminggu sekalii.. sudah berjalan dengan baik sih menurut saya..." (Informan 3)

Namun, beberapa informan menyatakan masih kurang dalam penyampaian informasi. Berikut kutipan wawancaranya :

"kayaknya masih kurang pengetahuan kayak kader mungkin kurang sosialisasi ke bawahnya..." (Informan 5)

“....kalo kurangnya itu.. eeee apa ya... kayanya eeee penyampaiannya gimana ya kalo yang dapet yang enak... soalnya kan bidan kadangkadang ngasih taunya wah ibu harus diperiksa lebih lan.. inihnih..kena nih... gitu. hehehe.. heehh.. dicurigain... itu doang sih kayanya penyampaian yang enaknya gimana gitu.. dicari solusinya.. biar dia gak langsung down gitu.." (Informan 7)

\section{Pembahasan}

\section{Input}

Man

Kemenkes (2015) pada Permenkes No. 34 Tahun 2015 tetang penanggulangan kanker payudara dan kanker serviks telah menetapkan bahwa tenaga pelaksana IVA yaitu Bidan, Dokter umum yang telah dilatih dan dokter spesialis Obgyn. Hal ini sesuai dengan hasil penelitian bahwa sumber daya yang terlibat pada Program IVA di puskesmas yaitu bidan yang berjumlah 10 orang. Dalam hal ini, jumlah petugas yang melaksanakan IVA sudah cukup.

$$
\text { Penelitian Riyadini (2015) }
$$

menyatakan bahwa tenaga pelaksana yang kurang menyebabkan tidak maksimalnya pelaksanaan suatu program. WHO mengidentifikasi 4 jenis ketidakberimbangan dalam hal penyediaan SDM yaitu dalam hal jumlah, kualifikasi, distribusi dan kegagalan kebijakan sebelumnya (Darmawan dan Sjaff, 2016). Menurut Indiahono (2009) kegagalan dalam implementasi sering terjadi karena sumber daya manusia yang tidak mencukupi, tidak memadai, ataupun tidak kompeten dibidangnya. Winarno (2016) menyatakan bahwa kekurangan staf juga akan menimbulkan persoalan pelik menyangkut implementasi kebijakan yang efektif.

Money

Pasien yang melakukan pemeriksaan IVA tidak dikenakan biaya bagi pasien yang memiliki BPJS atau jaminan kesehatan nasional yang berlaku di puskesmas tersebut, namun bagi yang tidak memiliki kartu jaminan kesehatan nasional dikenakan biaya sebesar Rp 25.000. Hal tersebut sesuai dengan peraturan pemerintah bahwa pasien yang memiliki Jaminan Kesehatan Nasional yang berlaku, tidak dikenakan biaya apabila sesuai dengan syarat dan prosedur yang berlaku (Kemenkes RI, 2015).

Hal ini sejalan dengan penelitian Riyadini (2015) bahwa pasien yang tidak memiliki jaminan kesehatan dikenakan biaya sebesar Rp. 25.000,- . Penelitian Putri (2015) Biaya yang harus dikeluarkan oleh masyarakat dalam pemeriksaan IVA adalah gratis, pasien hanya harus membawa, Kartu Tanda Pengenal (KTP), Kartu Keluarga, Kartu BPJS yang bisa membuktikan bahwa masyarakat bertempat tinggal di Deli Serdang

Method 
Sesuai dengan pedoman pada Permenkes No. 34 tahun 2015 bahwa deteksi dini dapat dilaksanakan pada acaraacara tertentu dengan berkoordinasi dan bekerja sama dengan lintas program dan lintas sektor seperti peringatan hari besar, percepatan deteksi dini dan tempat pelaksanaan tidak hanya di fasilitas kesehatan namun bisa di kantor, pusat keramaian yang memenuhi syarat untuk melakukan pemeriksaan IVA dibawah koordinasi FKTP setempat. Dari hasil penelitian, pelaksanaan program IVA di puskesmas bekerja sama dengan bidan praktek swasta terdekat dan biasanya dilakukan setiap satu tahun sekali.

Metode dalam pelaksanaan program IVA di puskesmas yaitu selain di hari besar/peringatan juga ada kegiatan rutin yang dilaksanakan di puskesmas yaitu pada saat pelayanan KB. Kemenkes (2015) menyatakan bahwa untuk percepatan target cakupan Puskesmas/Fasilitas Kesehatan Tingkat Pertama, kegiatan deteksi dini dapat bermitra/berintegrasi dengan program Infeksi Menular Seksual (IMS) dan Integrasi dengan Program Keluarga Berencana (KB).

\section{Material}

Dari hasil penelitian, sarana dan prasarana untuk program IVA berupa Lampu Sorot, Kain, Tempat Tidur / Meja Periksa, Kursi Periksa dan Ruang periksa. Sarana dan prasarana ini keadaannya baik dan jumlahnya telah sesuai dengan Peraturan Menteri Kesehatan No 34 Tahun 2015 tentang penanggulangan kanker payudara dan kanker leher rahim. Hal ini sejalan dengan penelitian Riyadini (2015) bahwa sarana dan prasarana dalam program IVA dalam keadaan lengkap dan baik sesuai dengan permenkes no 34 tahun 2015.

Menurut penelitian mursyid (2003) menyatakan bahwa pelaksanaan suatu program selalu membutuhkan berbagai sarana dan prasarana yang mendukung sehingga program tersebut dapat terlaksana sesuai dengan yang telah direncakan. Tanpa ketersediaan sarana dan prasarana, suatu kegiatan tidak dapat terselesaikan sebagaimana seharusnya, bahkan akan mengalami hambatan atau tidak berjalan dengan lancar.

\section{Machine}

Alat dan bahan merupakan kommponen penting bagi pemeriksaan IVA. Kemenkes (2015) mengemukakan bahwa alat yang digunakan untuk pemeriksaan IVA yaitu kapas lidi, speculum, wadah untuk speculum, ember ukuran sedang, cuka/asam asetat, dan klorin. Dalam pelaksanaannya di puskesmas, alat yang digunakan untuk pemeriksaan IVA sudah lengkap dan dalam keadaan baik. Namun, dalam hal jumlah ada beberapa yang tidak sesuai dengan ketentuan yang ditetapkan oleh kemenkes, tetapi hal ini tidak berpengaruh terhadap hasil dan pemeriksaan IVA. Juga tidak adanya pelaratan untuk pemeriksaan krioterapi, sehingga pasien yang dicurigai IVA positif akan diperiksakan lebih lanjut ke dokter kemudian di rujuk ke fasilitas kesehatan tingkat lanjut.

\section{Proses}

\section{Sumber Daya}

Dari hasil penelitian bahwa pada puskesmas, bidan yang melaksanakan IVA belum ada yang dilatih. Hal ini tidak sesuai dengan peraturan menteri kesehatan nomor 34 tahun 2015 tentang penanggulangan kanker payudara dan kanker leher rahim, yaitu petugas yang melayani IVA yaitu bidan terlatih, dokter umum terlatih dan dokter spesialis obgyn. Namun, bidan yang melaksanakan IVA ini merupakan bidan yang telah berpengalaman lama tetapi belum mendapat pelatihan, karena pernah ada yang mengikuti pelatihan tetapi di mutasi. Putri (2015) menyatakan bahwa pengalaman saja tidak cukup, diperlukan pelatihan yang harus diberikan kepada mereka, untuk menambah kompetensi mereka dalam melakukan pemeriksaan IVA dan juga menambah rasa percaya diri, tanggung jawab dan merasa sebagai bagian dari program tersebut.

Dalam pelaksanaan sebuah implementasi kebijakan, wewenang 
merupakan hal yang penting. Wewenang ini akan berbeda - beda di setiap program. Wewenang ada dalam banyak bentuk, mulai dari memberi bantuan hingga memaksakan perilaku (Winarno, 2016). Suryani (2018) menyatakan bahwa pemberian kewenangan terhadap pelaksana kebijakan memberikan dampak besar kepada tujuan yang akan dicapai. Dalam hal ini, petugas yang diberikan wewenang untuk melakukan pemeriksaan IVA yaitu bidan di puskesmas hal ini sesuai dengan permenkes no 34 tahun 2015.

\section{Komunikasi}

Menurut Edwards dalam Winarno (2016) persyaratan pertama bagi implementasi kebijakan yang efektif adalah bahwa mereka yang melaksanakan keputusan harus mengetahui apa yang mereka lakukan. Hal ini sejalan dengan hasil penelitian bahwa seluruh informan telah mengetahui bagaimana dan seperti apa program IVA itu. Dengan telah mengetahui terkait dengan program IVA, para pelaksana dapat dianggap telah baik dalam menyampaikan informasi terkait dengan program IVA.

Selain langsung dengan pasien, salah satu bentuk penyaluran informasi dalam program IVA di puskesmas ini juga disampaikan ketika dilakukannya lokakarya mini dan penyampaian langsung kepada pasien. Lokakarya mini ini dilakukan untuk pemantauan hasil kerja puskesmas dan tersusunnya rencana kerja di tahun berikutnya (Makkasau dan Makkasau, 2011). Dengan diadakannya lokakarya mini ini, dapat membangun komunikasi yang baik antar petugas puskesmas dengan lintas sector yang ada seperti kelurahan yang dibawahi oleh puskesmas, RT dan RW setempat, tokoh - tokoh masyarakat, kader dan sebagainya.

Sosialisasi harus lebih ditingkatkan kembali kepada masyarakat dan juga kader karena salah satu fungsi puskesmas yaitu sebagai pusat pemberdayaan masyarakat dimana puskesmas selalu berupaya agar perorangan terutama pemuka masyarakat, keluarga dan masyarakat termasuk dunia usaha memiliki kesadaran, kemauan dan kemampuan melayani diri sendiri dan masyarakat untuk hidup sehat berperan aktif dalam memperjuangkan kepentingan kesehatan (Syafrudin, dkk, 2009). Penelitian yang dilakukan aleh Anggraini (2015) menyatakan bahwa komunikasi memiliki pengaruh paling besar terhadap implementasi. Hal tersebut karena komunikasi merupakan faktor penting yang mempengaruhi kecenderungan karakter puskesmas dan sikap pelaksana.

\section{Disposisi}

Dari hasil penelitian, puskesmas dan para kader merespon positif program IVA tersebut. Hal ini menunjukkan bahwa petugas dan kader puskesmas telah menerima program IVA ini dijalankan. Anggraini (2015) dalam penelitiannya menyatakan bahwa Pembentukan sikap dan peningkatan dukungan puskesmas merupakan faktor penting yang berpengaruh langsung terhadap implementasi. Perlu adanya dukungan puskesmas dalam menciptakan adanya kejasama dari berbagai pihak didalam organisasi puskesmas diantaranya kerja tim, penciptaan lingkungan kerja yang kondusif dan penetapan tentang dilaksanakannya program IVA ini diwilayah kerjanya serta upaya monitoring melalui supervisi baik dari Kepala puskesmas maupun dari dinas kesehatan.

Setiap kebijakan, membutuhkan pelaksana yang mau untuk berkomitmen dalam menjalankan sebuah implementasi. Perilaku komitmen dapat dilihat jika petugas melakukan hal yang diharapkan, menghormati norma-norma organisasi, serta menuruti peraturan dan ketentuan yang berlaku. Dari hasil penelitian, Puskesmas telah berkomitmen untuk rutin melaksanakan program IVA sebanyak seminggu sekali bertepatan dengan pelayanan $\mathrm{KB}$, hal ini ditujukan untuk mencapai cakupan pemeriksaan IVA di puskesmas.

\section{Struktur Birokrasi}

Stuktur birokrasi Edwadrs III adalah mekanisme kerja yang dibentuk untuk mengelola pelaksanaan sebuah kebijakan. Ia 
menekankan perlu adanya Standart Operating Procedure (SOP) yang mengatur tata aliran pekerjaan di antara para pelaksana (Anggara, 2014). SOP menyeragamkan tindakan-tindakan dari para pejabat organisasi yang kompleks dan tersebar luas (Winarno, 2016).

Hasil penelitian menunjukkan bahwa tidak adanya SOP khusus yang mengatur tentang pelaksanaan program IVA di puskesmas. Hal ini dikarenakan Program IVA ini merupakan program tambahan. Anggraini (2015) menyatakan bahwa Kejelasan informasi sangat bermakna dalam pelaksanaan suatu program kebijakan di puskesmas. Jati, dkk (2017) menyatakan bahwa tidak jelasnya mekanisme, sistem dan prosedur kebijakan, pembagian tugas pokok, fungsi, kewenangan, dan tanggung jawab diantara para pelaku kebijakan menentukan gagalnya pelaksanaan suatu kebijakan.

3. Output

Studi implementasi menambahkan suatu dimensi baru kepada analisis kebijakan (Winarno, 2016). Implementasi merupakan suatu tindakan pelaksanaan dari suatu kebijakan untuk mencapai tujuan suatu kebijakan.

Dari hasil wawancara, seluruh informan menyatakan bahwa implementasi sudah baik karena telah dilakukan secara rutin, hanya saja masih terdapat masyarakat yang takut akan pemeriksaan IVA tersebut, juga kader yang masih kurang dalam sosialisasi ke masyarakat. Jati, dkk. (2017) menyatakan Puskesmas yang mengalami peningkatan cakupan cenderung memiliki sikap dan komitmen serta komunikasi yang lebih menonjol dibandingkan dengan puskesmas yang mengalami penurunan cakupan.

\section{Kesimpulan dan Saran}

Berdasarkan hasil dan pembahasan, maka dapat ditarik kesimpulan sebagai berikut:

1. Input pada Program IVA di Puskesmas Bojongsari yaitu :

a. Jumlah Sumber Daya untuk program IVA di Puskesmas Bojongsari sudah mencukupi. b. Pelaksanaan Program IVA dilakukan pada saat pelayanan KB.

c. Sarana prasarana dan Alat untuk Program IVA dalam keadaan baik dan jumlahnya mencukupi dan sesuai dengan pedoman dari kemenkes

d. Pasien yang melakukan pemeriksaan IVA tidak dikenakan biaya bagi pasien yang memiliki jaminan kesehatan nasional, namun bagi pasien umum dikenakan biaya sebesar Rp 25.000.

2. Proses pada program IVA di Puskesmasm Bojongsari berupa :

a. Petugas yang melaksanakan Program IVA, belum mendapatkan pelatihan.

b. Salah satu bentuk penyaluran informasi yaitu dengan adanya lokakarya mini juga sosialisasi langsung dengan pasien. Pelaksana IVA memberikan respon positif terhadap program IVA ini, mereka juga berkomitmen untuk melaksanakan program IVA secara rutin

c. Belum adanya SOP yang mengatur terkait dengan program IVA di puskesmas.

3. Output pada Program IVA di Puskesmas Bojongsari berupa :

Implementasi program IVA di puskesmas Bojongsari sudah Baik dalam hal pelaksanaan program yang sudah rutin

Dari hasil penelitian, maka penulis dapat memberikan beberapa saran, yaitu :

1. Bagi Puskesmas :

a. Dorongan dari puskesmas kepada kader agar lebih aktif dalam melaksanakan program - program yang bekerjasama dengan puskesmas

b. Perlu dilakukan pelatihan bagi petugas IVA, juga refresh materi terkait dengan program IVA kepada petugas dan kader yang terlibat dalam program IVA.

c. Melakukan evaluasi untuk menilai dan meningkatkan kinerja petugas dalam pelaksanaan program IVA.

d. Meningkatkan sosialisasi dan penyuluhan terkait dengan Program IVA di Puskesmas 
2. Bagi Peneliti Selanjutnya

a. Diharapkan mampu mengembangkan variabel - variabel penelitian yang belum di teliti.

b. Menambahkan pasien terkait dengan program IVA di Puskesmas sebagai sampel penelitian.

\section{Referensi}

[1] Anggara, Sahya. (2014). Kebijakan Publik. Bandung : CV. Pustaka Setia.

[2] Anggraini, Fitria Dwi. (2015). Faktor yang Mempengaruhi Implementasi Program Deteksi Dini Kanker Serviks Melalui Pemeriksaan IVA (Infeksi Visual Asam Asetat) di Puskesmas Wilayah Kota Surabaya. Jurnal Ilmiah Kesehatan. Volume 8 Nomor 1, 29 - 40.

[3] Darmawan, Ede Surya dan Amal Chalik Sjaff. (2016). Administrasi Kesehatan Masyarakat : Teori dan Praktik. Jakarta : Raja Grafindo.

[4] Dinas Kesehatan Kota Depok. (2017). Profil Kesehatan Kota Depok 2017. Depok : Dinas Kesehatan Kota Depok.

[5] Dinas Kesehatan Provinsi Jawa Barat. (2017). Profil Kesehatan Provinsi Jawa Barat 2017. Bandung : Dinas Kesehatan Provinsi Jawa Barat.

[6] Indiahono, Dwiyanto. (2009). Kebijakan Publik Berbasis Dynamic policy Analisys.Yogyakarta: Gava Media

[7] International Agency for Research on Cancer. (2017). World Cancer Day 2017. Geneva : World Health Organization. Diakses pada 25 Januari 2019. https://www.iarc.fr/featured-news/mediacentre-iarc-news-ecd-2017/

[8] Jati, Sutopo Patria, Ayun Sriatmi, dan Meytri Saraswati. (2017). Analisis Implementasi Program Deteksi Dini Kanker Serviks Melalui Metode Inspeksi Visual Asam Asetat (IVA) di Puskesmas Kota Semarang. Jurnal Kesehatan Masyarakat. Volume 5 Nomor 4, 85 - 95.

[9] Kementrian Kesehatan Republik Indonesia, Direktorat Pengendalian Penyakit Tidak Menular. (2015). Panduan Program Nasional Gerakan Pencegahan dan Deteksi Dini Kanker Leher Rahin dan Kanker
Payudara. Jakarta : Kementrian Kesehatan RI.

[10] Kementrian Kesehatan Republik Indonesia, Direktorat Pengendalian Penyakit Tidak Menular. (2016). Profil Penyakit Tidak Menular. Jakarta : Kementrian Kesehatan RI.

[11] Kementrian Kesehatan Republik Indonesia. (2017) Data dan Informasi: Profil Kesehatan Indonesia Tahun 2017. Jakarta : Kementrian Kesehatan Republik Indonesia.

[12] Makkasau, Kasman dan Sriyana Makkasau. (2011). Manajemen Program Bantuan Operasional Kesehatan dan Jaminan Sosial. Tangerang : Orbit Cendekia.

[13] Mursyid, H. (2003). Pelaksanaan Program Usaha Sekolah di Dinas Kesehatan Pemerintah Kota Medan Tahun 2003. Skripsi. Universitas Sumatera Utara.

[14] Peraturan Menteri Kesehatan Nomor 34 Tahun 2015 tentang Penanggulangan Kanker Payudara dan Kanker Leher Rahim

[15] Puskesmas Bojongsari. Profil Puskesmas Bojongsari Tahun 2017.

[16] Putri, Wan Elyda. (2015). Analisis Implementasi Program Deteksi Dini Kanker Serviks Dengan Metode IVA di Puskesmas Tanjung Morawa Kabupaten Deli Serdang Tahun 2015. Skripsi : Universitas Sumatera Utara.

[17] Riyadini, Marsya Savitri. (2015). Analisis Implementasi Program Deteksi Dini Kanker Serviks dengan Metode Inspeksi Visual Asam Asetat (IVA) di Puskesmas Kota Semarang Tahun 2015. Skripsi : Universitas Negeri Semarang

[18] Sulistiowati, dan Sirait. (2014). Pengetahuan tentang Faktor Risiko, Perilaku dan Deteksi Dini Kanker Serviks dengan Inspeksi Visual Asam Asetat (IVA) pada Wanita di Kecamatan Bogor Tengah, Kota Bogor. Buletin Penelitian Kesehatan. Volume 42 Nomor 3. 193 - 202.

[19] Suryani, Amalia. (2018). Analisis Proses Akreditasi Puskesmas Sindang Barang Kota Bogor Tahun 2018. Skripsi : Universitas Ibn Khaldun Bogor.

[20] Susanti, Aris. (2010). Faktor-Faktor Yang Berhubungan Dengan rendahnya Kunjungan Inspeksi Visual Asam Asetat 
(IVA) Di Wilaya Kerja Puskesmas Halmahera Kecamatan Semarang Timur Tahun 2010. Skripsi. Universitas Negri Semarang.

[21] Winarno, Budi. (2016). Kebijakan Publik Era Globalisasi : Teori, Proses dan Studi Kasus Komparatif. Yogyakarta : Center of Academic Publishing Service

[22] World Health Organization. (2017). Noncomunicable Disease Progress Monitor 2017. Geneva : World Health Organization. 